\title{
Carpal Joint
}

National Cancer Institute

\section{Source}

National Cancer Institute. Carpal Joint. NCI Thesaurus. Code C32264.

A joint formed between carpal bones. 